\title{
Development of Sharia Economics Textbook for Economic Education Student Lectures in the Era of Industrial Revolution 4.0
}

\author{
Melisa Wahyu Fandyansari, Putri Vina Sefaverdiana
}

Economic Education Departement, IKIP Budi Utomo, Malang, Indonesia

The era of the industrial revolution 4.0, which is currently trending in Indonesia, has made various aspects of people's lives change more advanced and completely based on technology. Therefore, educators are required to produce students who have knowledge, soft skills, and ability in the field of adequate technology. One of the programs prepared by the Economic Education Study Program is the mastery of knowledge of Sharia economic material so that one day graduates can become compatible in various fields of work, especially banking, which is currently rife with Sharia banks. The addition of this knowledge through the development of Sharia economics textbooks conducted by the RND method from Dick and Carey. The results of the pretest-posttest test, expert validation test, small scale test, and large scale test, obtained the results that the textbooks are included in the good category and are suitable for use.

Keywords: Sharia Economics Textbooks, Economic Education, Technology

OPEN ACCESS

ISSN 2503-3077 (Online) (online)

ISSN 2503-3077 (print)

${ }^{\star}$ Correspondence:

Received: 21 February 2020 Accepted: 21 March 2020

Published: 21 April 2020

Citation:

Fandyansari MW and Sefaverdiana PV (2020) Development of Sharia Economics Textbook for Economic Education Student Lectures in the Era of Industrial Revolution 4.0.

Perisai : Islamic Banking and Finance Journal. 4:1.

doi: 10.21070/perisai.v4i1.513 


\section{INTRODUCTION}

The 4.0 industrial revolution in Indonesia currently requires a person to have capabilities in the field of technology, information. The occurrence of industrial revolutions, which also occurred in various worlds was a revolution that had a profound effect on the world's ecosystems and the way of life Baenanda (2019). The main emphasis of the industrial revolution is the improvement of technology or industrial changes that were carried out manually but now are turning to be based on technological progress. In the past, factory activities carried out by humans have now switched to automation from systems that are connected to machines, so people do not need humans for their activities. This is done by industry players for reasons of time efficiency, energy efficiency, and cost efficiency and is known as a smart factory Prasetyo and Trisyanti (2019) . The industrial revolution in the world has taken place in four stages, namely: 1) the industrial revolution 1.0 that occurred in the 18th century through the invention of a steam engine that impacted the mass production system of goods, 2) the $2.0 \mathrm{rev}$ olution occurred in the century 19-20 where it was marked by the production process using electricity which made production costs cheaper, 3 ) the 3.0 revolution occurred around the 1970 s with the use of computers in production activities, and 4) the industrial revolution 4.0 occurred around 2010-2012 which first introduced by Germany as Industrie 4.0. In fact, Industrie 4.0 is one of Germany 2020's modern technology strategy projects, which is implemented through improving manufacturing technology, creating a consistent strategic policy framework, and setting priorities in the face of global competition.

In the Kamus Besar Bahasa Indonesia (KBBI) or Indonesian Language Dictionary, Revolution is interpreted as a change in state administration (government or social conditions) carried out with violence (such as with armed resistance), or can also be interpreted as sufficient changes fundamental in a field. While the industry is the activity of processing or processing goods using facilities and equipment. Combined, the industrial revolution, according to KBBI means a radical change in the effort to achieve production by using machines, both for movers and processors. Or it can be concluded that the industrial revolution is a change that occurs in the industrial world where technology becomes the core of production activities.

The development of the massive industrial world 4.0 occurred mainly in Indonesia, inevitably demanding students to become prospective graduates in accordance with the demands of the world of work, and a university has an obligation to prepare and equip prospective graduates with various matters relating to the industrial revolution. Changes in patterns that occur in the industrial world, requires that a student especially IKIP Budi Utomo economic education students not only learn or master the material on how to become a teacher or educator but also must enrich themselves with the mastery of skills and competencies relevant to the current era in particular in the economic field. So that after the student com- pletes his studies, he will become a graduate who is ready to become a teacher who is characterized, competent and innovative, and is compatible with other fields of work or becomes an entrepreneur or works in the economy according to the vacancies in the workforce. One of the provisions provided is the material of Sharia economics which is currently becoming a trend in Indonesia, especially Sharia banks.

According to Yusuf Qardhawi, Sharia economics is "an economy based on divinity, which is dwelling on Allah SWT and utilizing means that do not violate the rules of Sharia" Mustika (2019) . Meanwhile, according to S.M. Hanazuzzaman, sharia economics is "the knowledge and application of sharia teachings and rules that prevent injustice in the search for and use of available resources, which are used to meet human needs and to carry out human obligations to the SWT", Mustika (2019). Sharia economics is one branch of economics which in its implementation is based on Sharia law. The Sharia law used can originate from the Quran, Sunnah or Ijma and Qiyas. The use of Sharia economics in the community, is intended for the benefit of society, and the benefit or welfare of this community is not only measured from the material aspects but also pay attention to social, mental, spiritual and environmental impacts Annaisabiru (2018).

\section{[Figure 1 about here.]}

The preparation of textbooks is one of the usual activities carried out in learning activities. Textbooks contain a collection of materials compiled by teachers to facilitate learning activities. The preparation is based on $\mathrm{KD}$ or basic competencies in the curriculum used to fit the material taught and useful for students. Kurniasih said that "textbooks are teaching materials written by teachers and derived from the basic competency-based curriculum, so as to give meaning to students who use them" Susanti (2018) . In addition, Kurniasih also explained that there are several objectives for writing textbooks Susanti (2018), including 1) to provide books that fit the needs of students and technological guidance, 2) can encourage writers or teachers to be more creative in share their knowledge with students and the public or other readers, 3) can make teachers more updated knowledge and knowledge, and 4) teachers or writers can publish books to fulfill credit scores determined by the government. Textbooks used in lectures must have certain characteristics, some of which are: 1) can arouse students' interest in reading, 2) are designed and written for students, 3) contain instructional objectives, 4) are used by lecturers and students in the lecture process, 5) arranged in a flexible, systematic, and structured pattern according to the needs of students and according to the competencies to be achieved, 6) focus on opportunities for students to practice a lot, 7) there is a summary, 8) there is feedback, 9) the style of writing is communicative and uses words that are easy to understand, 10) can accommodate student learning difficulties, and 11) easy to use.

In IKIP Budi Utomo Economic Education Study Program, Sharia economics courses are presented in semester five (5) or 
in the odd semesters. MK with code EKO227 and 2 credits. In conducting lectures, there are obstacles faced by lecturers, in this case, researchers, namely most or almost $80 \%$ of students are students from Nusa Tenggara and Kalimantan who are nonMuslim students who have never known, heard or said the term Sharia words in Sharia economic material very much. Then the next obstacle is the book that is on the market and becomes a reference, so many sentences or quotations from the Qur'an and this is one of the difficulties for students

The course material developed into sharia economic textbook is about the understanding of Islamic economics and how the application of Islamic economics in Indonesia. Therefore, the researcher wants to help solve students' problems related to books so that students can recognize Sharia economic lectures well, be able to listen, understand the material and master the material well so that later they can become graduates who are compatible and in accordance with what is expected by the business world in the era of the industrial revolution 4.0 at the moment. Therefore the purpose of this study is to develop sharia economic textbooks for students of economic education in the era of the industrial revolution 4.0.

\section{METHODOLOGY}

Research on the Sharia Economics Textbook for Economic Education Student Lectures in the Industrial Revolution Era 4.0 was carried out using Research \& Development (R\&D). According to Sugiyono, R \& D method is a process for developing and validating a product Sugiyono (2014). The development research steps according to Sugiyono are potential and problem, data collection, product design, design validation, design revision, product testing, product Revision, Usage Test, Product Revision, and Mass Production.

In practice, this study uses $R \& D$ with models from Dick and Carrey. This model has a 10-step research stage, but only nine step are used in this study, namely (1) Identifying the objectives of general lectures, (2) Recognizing the input, characteristics, and characteristics of students participating in Islamic economics courses, (3) Conducting analysis of Islamic economic subjects, (4) Formulating specific objectives of Islamic economic courses, (5) Developing items reference tests on textbooks, (6) Develop instructional strategies,

(7) Develop and write instructional media tools and media, (8) Design and carry out formative evaluations, (9) Design and carry out summative evaluations

The effectiveness test of the use of Sharia economics textbooks is carried out experimentally through pretest and posttest. The effectiveness test was conducted on the 2016 economic education student of the IKIP Economic Education Study Program Budi Utomo Malang, located on the IBU Campus Jl. Citandui no 46 Malang with a total of 110 research subjects in economic education. Previously this instrument has been tested so as to get a reliability value of 0.777 which means that the data is quite reliable. Data collection techniques using questionnaires, both questionnaires from students and questionnaires obtained from four experts or textbook validators, namely validators of Sharia economics material experts, validators of material matter experts, language expert validators, and media expert validators. In addition to the pretest and posttest, the effectiveness test of the book is also carried out on students by carrying out a small scale test and a large scale test of the textbook.

\section{RESULT AND DISCUSSION}

At the stage of identifying the objectives of general lectures, recognizing the input and characteristics of students participating in Islamic economics courses, conducting analysis of Islamic economic subjects, formulating specific objectives of Islamic economic courses, and developing items reference tests on textbooks are well implemented. This Sharia economic textbook consists of some material described in Table $\mathbf{1}$.

\section{[Table 1 about here.]}

Table 1 shows that the process of formulating specific objectives of Islamic economic courses and developing items reference tests on textbooks has been carried out. The book contains several subjects, namely the definition of economic sharia, economic sharia objectives, the application of economic sharia and problems in economic sharia. All four subjects have been revised with the advice of experts. On the subject of sharia economic implementation there are sub-subjects that integrate to fit with the current era and the problems described in the textbook are also integrated into problems in the era of the industrial revolution 4.0.

From the research procedure, the results obtained from the pretest and posttest results obtained are the results of the pretest $72.5 \%$ and after using the textbook or posttest test the average results obtained $83.6 \%$. The use of $\mathrm{R} \& \mathrm{D}$ research of the Dick and Carey method has nine steps as discussed above. After the draft textbook is finished, the next thing is to test the product. The first test conducted is a test for an expert validator. From Sharia economic material experts, the validator test results obtained by $83.3 \%$ and get the title appropriate or appropriate to use. The next expert was an expert in a material matter which got $75.2 \%$ with a decent title and got advice to add a discussion about the pillar of virtue besides benefit. The next expert is language, from linguists obtained test results of $81.7 \%$. Finally is the validator of media experts, which obtained a test number of $78.6 \%$.

After going through the validation test stage, the next is product testing with students. There are two tests, namely the small scale test and the large scale test. Small scale tests conducted on 10 and 15 August 2019 with the number of participants of 40 students, the results obtained $82.6 \%$. And a large-scale test with the number of participants of 70 students, obtained a value of $86.3 \%$ and each test result included in the category or good qualifications. From several tests conducted, both pretest and 
posttest tests, expert validation test, small scale test and finally the large scale test, the conclusion is that the textbooks used in Economic Education students are included in both criteria and included in the proper category to be used to support lectures Sharia economics.

The Industrial Revolution 4.0 is a phenomenon that responds to changes and technological developments marked by the development of Artificial Intelligence (AI), machine learning, biotechnology, blockchain, the Internet of Things (IoT), even to driverless vehicles Shahroom and Hussin (2018). These changes then have an impact on the form of human interaction, as well as how humans form a harmony with developing technology to get solutions, solve problems, and of course, find new innovation possibilities that can help improve the quality of people's lives Hussin (2018). Changes in the form of this interaction do not affect just one aspect, but almost all aspects of human life, including the world of education and schooling, then the term Education 4.0 appears Hussin (2018).

Thus, the impact of industry 4.0 should be able to be utilized by schools to develop an educational process that is not constrained by current technological developments. This condition will slowly cause a weak moral consensus in the community, so that in order to survive, the community must continue to be able to build and develop that consensus, including within the scope of schooling.

\section{REFERENCES}

Annaisabiru, A. (2018). Pengertian Ekonomi Syariah dan Karakteristiknya. ruangguru. https://blog.ruangguru.com/pengertian-ekonomi-syariah-dankarakteristiknya. (Accessed on 2019-10-10).

Baenanda, L. (2019). Mengenal Lebih Jauh Revolusi Industri 4.0. Binus University. https://binus.ac.id/knowledge/2019/05/mengenal-lebih-jauh-revolusiindustri-4-0/. (Accessed on 2019-10-10).

Hussin, A. A. (2018). Education 4.0 Made Simple: Ideas For Teaching. International Journal of Education and Literacy Studies 6, 92-92. doi: 10.7575/aiac.ijels.v.6n. 3p.92.

Mustika, A. R. (2019). Apa definisi ekonomi syariah? Ekonomi syariah adalah cabang ilmu pengetahuan sosial yang di dalamnya mempelajari masalah ekonomi rakyat yang diilhami oleh syariat Islam. Finansialku.com. https: //www.finansialku.com/definisi-ekonomi-syariah-adalah/. (Accessed on 201910-10).

Prasetyo, B. and Trisyanti, U. (2019). Revolusi Industri 4.0 Dan Tantangan Perubahan Sosial. Prosiding SEMATEKSOS 3 "Strategi Pembangunan Nasional Menghadapi Revolusi Industri 4.0”.

\section{CONCLUSION}

From several tests conducted, both pretest and posttest tests, expert validation test, small scale test and finally the large scale test, the conclusion is that the textbooks used in Economic Education students are included in both criteria and included in the proper category to be used to support lectures Sharia economics.

\section{AUTHOR CONTRIBUTION}

All authors contributed in writing this manuscript. Melisa Wahyu Fandyansari (first author) contributed to the writing of the entire manuscript, while Putri Vina Sefaverdiana (second author) contributed to the analysis and interpretation of data.

\section{FUNDING}

Funding for this research was supported by the Ministry of Education and Culture of the Republic of Indonesia (KEMENDIKBUD) through the Beginner Lecturer Research (PDP) program.

\section{ACKNOWLEDGEMENTS}

We thank reviewers, editors and all those who have contributed to the publication and research process.

Shahroom, A. A. and Hussin, N. (2018). Industrial Revolution 4.0 and Education. International Journal of Academic Research in Business and Social Sciences 8, 314319. doi: 10.6007/ijarbss/v8-i9/4593.

Sugiyono (2014). Metode Penelitian Pendidikan (Jakarta).

Susanti, M. (2018). Pengembangan Buku Ajar Penulisan Artikel Jurnal Untuk Meningkatkan Kualitas Argumen Pada Mahasiswa Program Studi PBSI Program Magister Universitas Sanata Darma Yogyakarta.

Conflict of Interest Statement: The authors declare that the research was conducted in the absence of any commercial or financial relationships that could be construed as a potential conflict of interest.

Copyright (C) 2020 Fandyansari and Sefaverdiana. This is an open-access article distributed under the terms of the Creative Commons Attribution License (CC BY). The use, distribution or reproduction in other forums is permitted, provided the original author(s) and the copyright owner(s) are credited and that the original publication in this journal is cited, in accordance with accepted academic practice. No use, distribution or reproduction is permitted which does not comply with these terms. 


\section{LIST OF TABLES}

1 Subjectand Content Categories of Sharia Economic Textbook

44 
TABLE 1 | Subjectand Content Categories of Sharia Economic Textbook

\begin{tabular}{ll}
\hline Subject & $\begin{array}{l}\text { Categories } \\
\text { Definition }\end{array}$ \\
$\begin{array}{l}\text { The goal of Sharia economic } \\
\text { The application of economic } \\
\text { Sharia }\end{array}$ & $\begin{array}{l}\text { Contains the objectives of Islamic economics and the benefits of Islamic economics } \\
\text { Contains the application of Islamic economics in the past and in the present }\end{array}$ \\
$\begin{array}{l}\text { Problem of Sharia economic } \\
\text { Contains questions about test questions in the form of problems from the application of Islamic economics and how to overcome } \\
\text { these problems }\end{array}$ \\
\hline
\end{tabular}




\section{LIST OF FIGURES}

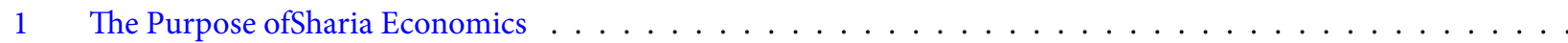




\section{Tujuan ekonomi syariah adalah falah.}

Falah yaitu kesuksesan yang hakiki berupa tercapainya kebahagiaan dalam segi materiil dan spiritual serta tercapainya kesejahteraan dunia dan akhirat.

ruang 